\title{
PENERAPAN CASCADING BALANCE SCORECARD DALAM PEMBUATAN PETA STRATEGI TI (STUDI KASUS: DIREKTORAT SISTEM INFORMASI UNIVERSITAS 17 AGUSTUS 1945 SURABAYA)
}

\author{
Yusrida Muflihah*, Agus Hermanto** \\ Teknik Informatika, Universitas 17 Agustus 1945 Surabaya \\ *yusridamuflihah@gmail.com,**agushermanto@gmail.com
}

\begin{abstract}
The application of IT at the University 17 Agustus 1945 Surabaya has not received special attention because the role of information technology is only seen as a business supporter and not a major business. These conditions cause several problems related to the management of information technology at the University 17 Agustus 1945 Surabaya, namely: (1) the application of information technology governance is not optimal, (2) the function of information technology does not yet have a clear strategic and objective direction, (3) The role and employee responsibilities within the Information Systems Department are clearly defined. The purpose of this study is to create an information technology strategy map by applying the cascading balance scorecard process. In achieving the research objectives, ten cascading balance scorecard stages will be carried out, namely analyzing division objectives, identifying the relevance of divisions, identifying customer divisions, identifying division activities, tabulating outputs, identifying customer outcomes, lowering corporate strategy targets to the Division, compiling a strategy map, and determining KPI as well as strategic initiatives. The results of this study are IT strategy maps that show an increase in information technology user satisfaction that will lead to improved performance in conducting academic / non-academic operational activities. In support of increasing IT user satisfaction, IT mastery strategies are needed by all university human resources and enhancing relationships with IT vendors. Whereas in supporting the improvement of the performance of academic / non-academic operational activities, information systems and optimization of IT asset management need to be supported
\end{abstract}

Keyword: cascading, balance scorecard, IT strategic

\section{Pendahuluan}

Keselarasan strategi bisnis dan strategi TI dibutuhkan agar fungsi TI dapat mendukung tujuan bisnis perusahaan. Selain itu hal ini penting untuk diterapkan mengingat investasi teknologi informasi merupakan investasi yang mahal dan mempunyai resiko yang tinggi bila organisasi tidak dapat mengelola aset teknologi informasi tersebut dengan baik. Pada tahun 2012 sebanyak 33\% dari pengeluaran per tahun perusahaan di Amerika Serikat digunakan untuk melakukan investasi teknologi informasi [1]. Sedangkan di Indonesia, sebanyak 57\% institusi, perusahaan dan pemerintahan menaikkan anggaran belanja teknologi informasi pada tahun 2014 yang diperkirakan totalnya mencapai US \$16,8 miliar, naik 12,5\% dari tahun 2013 [2]. Oleh karena itu adanya penyelarasan startegi bisnis dan strategi TI merupakan suatu kebutuhan bagi organisasi agar dapat dipastikan bahwa fungsi teknologi informasi memberikan nilai bisnis pada organisasi.

Sama halnya dengan sektor bisnis lain, teknologi informasi juga mempunyai peranan penting dalam sektor kesehatan seperti untag. Sebagian besar universitas tidak bisa terlepas dari penggunaan teknologi informasi dalam mendukung pelayanan pendidikan. Universitas 17 Agustus 1945 Surabaya merupakan salah satu universitas swasta yang ada di Surabaya. Sebagai salah satu universitas swasta yang terkemuka di Surabaya, Universitas 17 Agustus 1945 telah menerapkan teknologi informasi sebagai penunjang utama dalam pelayanan pendidikan. Namun demikian, penerapan TI pada Universitas 17 Agustus 1945 Surabaya ini belum mendapatkan perhatian khusus karena peran teknologi informasi hanya dipandang sebagai pendukung bisnis dan bukan menjadi core bisnis utama. Beberapa hal tersebut menyebabkan adanya beberapa masalah terkait dengan pengelolaan teknologi informasi pada Universitas 17 Agustus 1945 Surabaya, yaitu: (1) penerapan tata kelola teknologi informasi belum optimal, (2) fungsi teknologi informasi belum memiliki arah tujuan dan strategis yang jelas, (3) Peran dan tanggung jawab pegawai yang berada dalam Departemen Sistem Informasi terdefinisikan dengan jelas.

Berdasarkan permasalahan tersebut, sebagai organisasi yang mempunyai aktifitas teknologi informasi ini timbul kebutuhan akan adanya peta strategi teknologi informasi yang harus diselaraskan dengan tujuan 
Universitas 17 Agustus 1945 Surabaya sehingga fungsi TI mampu memberikan kontribusi terhadap tujuan Universitas 17 Agustus 1945 Surabaya. Sehingga, tujuan dari penelitian ini adalah membuat peta strategi teknologi informasi dengan menerapkan proses cascading balance scorecard. Metode cascading balance scorecard difungsikan untuk menyelaraskan Balanced Scorecard bisnis menjadi Functional Scorecard. Cascading ke functional scorecard merujuk pada penurunan atau penyelasaran ke suatu unit organisasi yang berada pada satu tingkat di bawah level organisasi. Proses cascading balance scorecard ini akan menghasilkan strategi unit bisnis yang berada pada level bawah untuk berkontribusi mencapai tujuan organisasi. Dalam mencapai tujuan penelitian, akan dilakukan sepuluh tahapan cascading balance scorecard yaitu menganalisis tujuan divisi, identifikasi relevansi divisi, identifikasi pelanggan divisi, identifikasi aktivitas divisi, tabulasi output, hasil dari identifikasi pelanggan, menurunkan sasaran strategi perusahaan ke Divisi, menyusun peta strategi, dan menentukan KPI serta inisiatif strategi.

\section{Metode Penelitian}

Dalam mencapai tujuan penelitian ini, yaitu peta strategi teknologi informasi pada Universitas 17 Agustus 1945, akan dilakukan proses cascading balance scorecard. Cascading balance scorecard diartikan sebagai penurunan atau penyelarasan Balanced Scorecard bisnis menjadi Functional Scorecard. Cascading ke functional scorecard merujuk pada penurunan atau penyelasaran ke suatu unit organisasi yang berada pada satu tingkat di bawah level organisasi [3]. Proses cascading balance scorecard ini akan menghasilkan strategi unit bisnis yang berada pada level bawah untuk berkontribusi mencapai tujuan organisasi. Unit bisnis yang akan diturunkan menjadi functional scorecard adalah Direktorat Sistem Informasi (DIREKTORAT SISTEM INFORMASI (DSI)). DIREKTORAT SISTEM INFORMASI (DSI) dipililih untuk dilakukan cascading dikarenakan DIREKTORAT SISTEM INFORMASI (DSI) merupakan unit bisnis di Universitas 17 Agustus 1945 yang bertanggungjawab atas kelangsungan TI. Berikut metodologi penelitian yang diterapkan dalam penelitian ini dengan menyesuaikan tahapan cascading balance scorecard.

1. Tujuan Divisi

Pada tahap pertama melakukan cascading balanced scorecard, akan dilakukan analisis visi dan misi dari Direktorat Sistem Informasi.

\section{Relevansi Divisi}

Pada tahap kedua, dilakukan identifikasi kontribusi dan pengaruh Direktorat Sistem Informasi terhadap peta strategi perusahaan.

\section{Pelanggan Divisi}

Pada tahapan ini dilakukan identifikasi pelanggan atau pihak yang berhubungan langsung dengan Direktorat Sistem Informasi tersebut dari pihak internal perusahan atau pihak eksternal.

4. Aktivitas Divisi

Identifikasi tugas pokok Direktorat Sistem Informasi. Tugas pokok Direktorat Sistem Informasi merupakan aktifitas atau tugas utama yang dijalankan oleh Direktorat Sistem Informasi tersebut.

\section{Identifikasi Harapan Pelanggan}

Pada tahapan ini dilakukan tabulasi output, hasil dari identifikasi pelanggan ditambahkan dengan ekspektasi pelanggan Direktorat Sistem Informasi tersebut.

\section{Menurunkan (cascading) Sasaran Strategi Perusahaan ke Divisi}

Pada tahap keenam, hal yang dilakukan adalah mengulang kembali langkah pertama yaitu mengidentifikasi sasaran strategis perusahaan yang harus diturunkan ke Direktorat Sistem Informasi kemudian menetukan sasaran strategis tambahan yang diperlukan oleh Direktorat Sistem Informasi.

\section{Memperhatikan Isu-isu Lokal}

Pada tahap ketujuh, merupakan serangkaian proses mengulang kembali tahap-tahap sebelumnya untuk melengkapi peta strategi. Proses ini akan memperhatikan kembali harapan pelanggan pada langkah kelima dan dikombinasikan dengan strategi Direktorat Sistem Informasi yang telah diperoleh untuk dipetakan ke dalam 4 perspektif IT Balanced Scorecard.

8. Konsolidasi dan Tes Logika

Pada tahap kedelapan ini akan dilakukan penyusunan peta strategi Direktorat Sistem Informasi dan mengidentifikasi hubungan sebab akibat di antara sasaran strategi yang diturunkan dari peta strategi perusahaan ke peta strategi Direktorat Sistem Informasi.

9. Memilih Key Performance Indicator (KPI)

Pada tahap kesembilan ini akan dilakukan identifikasi Key Performance Indicators (KPI) untuk setiap sasaran strategi Direktorat Sistem Informasi. 


\section{Menetukan Target KPI dan Inisiatif Strategis}

Pada tahap terakhir akan ditentukan target dan inisiatif strategi untuk mencapai sasaran strategis yang telah didefinisikan sebelumnya

\section{Hasil dan Pembahasan}

Pada bagian ini akan disampaikan hasil cascading balance scorecard pada Direktorat Sistem Informasi beserta dengan analisis yang mengarah pada hasil penelitian.

\subsection{Tujuan Direktorat Sistem Informasi (DIREKTORAT SISTEM INFORMASI (DSI))}

Langkah pertama dalam melakukan penurunan (cascading) adalah dengan melakukan penentuan tujuan Direktorat Sistem Informasi dengan menganalisis visi dan misi DIREKTORAT SISTEM INFORMASI (DSI) terhadap visi dan misi Untag Surabaya secara keseluruhan. Berdasarkan analisis pernyataan visi dan misi Direktorat Sistem Informasi, dapat diketahui dengan jelas tujuan dari Direktorat Sistem Informasi yaitu untuk mewujudkan pengembangan, pengelola, dan memastikan seluruh sistem yang beroperasi baik dalam pegembangan atau baru di lingkungan Yayasan Perguruan 17 Agustus 1945 Surabaya guna mendukung terciptanya tata kelola universitas yang baik melalui dukungan TI di lingkungan universitas.

\subsection{Relevansi DIREKTORAT SISTEM INFORMASI (DSI)}

Pada langkah ini akan melakukan identifikasi kontribusi dan relevansi DIREKTORAT SISTEM INFORMASI (DSI) terhadap peta strategi Untag Surabaya. Relevansi DIREKTORAT SISTEM INFORMASI (DSI) ini bertujuan untuk mengetahui keterkaitan antara strategi DIREKTORAT SISTEM INFORMASI (DSI) terhadap peta strategi organisasi sehingga dapat teridentifikasi strategi organisasi mana yang dapat didukung langsung oleh DIREKTORAT SISTEM INFORMASI (DSI). Identifikasi kontribusi DIREKTORAT SISTEM INFORMASI (DSI) terhadap strategi organisasi dilihat dari visi dan misi DIREKTORAT SISTEM INFORMASI (DSI), tugas pokok dan fungsi DIREKTORAT SISTEM INFORMASI (DSI) dan identifikasi proses-proses inti (core process) dari DIREKTORAT SISTEM INFORMASI (DSI). Setelah dilakukan analisis tersebut, terdapat 2 strategi organisasi yang ditelaah berdasarkan peta strategi organisasi yang dapat didukung langsung oleh Direktorat Sistem Informasi yaitu pada perspektif proses bisnis internal, Direktorat Sistem Informasi mendukung strategi Peningkatan dukungan sistem informasi dalam kegiatan akademik dan non akademik dan Pengembangan sistem informasi yang komprehensif. Salah satu tugas pokok Direktorat Sistem Informasi adalah Mengelola (menyusun, memantau, mengendalikan) kegiatan pengembangan TI dan mengembangkan infrastruktur TI berupa hardware dan software yang sesuai dengan blueprint dan standar tata kelola TI.

\subsection{Identifikasi Pelanggan}

Pelanggan didefinisikan sebagai pihak-pihak baik internal organisasi maupun eksternal yang terlibat langsung dengan proses bisnis dan merasakan pelayanan dari Direktorat Sistem Informasi . Pelanggan internal adalah pelanggan yang ada dalam lingkup organisasi tetapi di luar dari Direktorat Sistem Informasi . Sedangkan pelanggan eksternal adalah pelanggan yang berasal dari luar perusahaan. Pelanggan dari Direktorat Sistem Informasi ini juga dikategorikan menjadi 2 yaitu pelanggan internal dan eksternal. Pelanggan internal di Direktorat Sistem Informasi terdiri dari seluruh unit kerja dan instansi dibawah naungan Yayasan Perguruan 17 Agustus 1945 termasuk pula didalamnya tenaga pendidik, karyawan, mahasiswa/siswa. Sedangkan pihak eksternal terdiri dari pihak-pihak yang bekerja sama dengan Yayasan Perguruan 17 Agustus 1945 dan perusahaan IT Swasta dalam kerjasaman dibidang TI.

\subsection{Identifikasi Tugas Pokok dan Fungsi DIREKTORAT SISTEM INFORMASI (DSI)}

Pada langkah keempat ini akan dilakukan identifikasi terhadap tugas pokok dan fungsi atau proses-proses inti dari Direktorat Sistem Informasi. Tugas pokok atau proses inti merupakan aktivitas atau tugas utama yang dijalankan oleh Direktorat Sistem Informasi yang hasilnya memberi pengaruh secara langsung terhadap pemenuhan kebutuhan pelanggannya. Identifikasi tugas pokok dan fungsi atau proses ini dilakukan dengan metode wawancara kepada Direktorat Sistem Informasi. 




Gambar 1 Tugas Pokok dan Fungsi DIREKTORAT SISTEM INFORMASI (DSI)

\subsection{Identifikasi Harapan Pelanggan}

Pada aktivitas identifikasi harapan pelanggan ini akan dilakukan identifikasi ekspektasi pelanggan yang didasari oleh keluaran atau output dari tugas pokok dan fungsi dari Direktorat Sistem Informasi. Harapan pelanggan diperoleh dari wawancara baik secara langsung maupun via email. Wawancara dilakukan dengan beberapa pegawai yang dianggap telah mewakili. Beberapa hasil identifikasi harapan pelanggan dari Direktorat Sistem Informasi ditunjukkan dari tabel berikut.

\begin{tabular}{|c|c|c|c|}
\hline No & Output & Pelanggan & Harapan \\
\hline 1. & $\begin{array}{l}\text { Tersedianya pelayanan terkait } \\
\text { TI dan penanganan komplain } \\
\text { dan permintaan pengguna }\end{array}$ & $\begin{array}{ll}\text { - } & \text { Tenaga pendidik } \\
\text { - } & \text { Karyawan } \\
\text { - } & \text { Mahasiswa }\end{array}$ & $\begin{array}{l}\text { Tersedianya layanan TI yang } \\
\text { baik dan penanganan } \\
\text { komplain dan permintaan } \\
\text { pengguna TI yang direspon } \\
\text { dengan cepat dan tepat }\end{array}$ \\
\hline 2. & $\begin{array}{l}\text { Adanya pengawasan atau } \\
\text { pemantauan sehingga dapat } \\
\text { memastikan ketersediaan } \\
\text { layanan TI untuk mendukung } \\
\text { operasional universitas }\end{array}$ & $\begin{array}{l}\text { - } \text { Tenaga pendidik } \\
\text { - Karyawan } \\
\text { - Mahasiswa }\end{array}$ & $\begin{array}{l}\text { Adanya pengawasan dan } \\
\text { pemantauan yang berkala } \\
\text { sehingga dapat dipastikar } \\
\text { ketersediaan layanan TI dapa } \\
\text { optimal }\end{array}$ \\
\hline 3. & $\begin{array}{l}\text { Sumber informasi dan edukasi } \\
\text { terpercaya untuk para } \\
\text { pengguna terkait status } \\
\text { layanan, penanganan komplain } \\
\text { dan permintaan yang tersedia }\end{array}$ & $\begin{array}{l}\text { - Tenaga pendidik } \\
\text { - Karyawan } \\
\text { - Mahasiswa }\end{array}$ & $\begin{array}{l}\text { Tersedianya informasi yang } \\
\text { akurat dan terpercaya dan } \\
\text { dapat mengedukasi pengguna } \\
\text { layanan TI terkait status } \\
\text { layanan, penanganan } \\
\text { komplain dan permintaan } \\
\text { yang tersedia }\end{array}$ \\
\hline
\end{tabular}

Gambar 2 Identifikasi Harapan Pelanggan DIREKTORAT SISTEM INFORMASI (DSI)

\subsection{Cascading Sasaran Strategi Organisasi ke Direktorat Sistem Informasi}

Pada tahap ini peta strategi Direktorat Sistem Informasi akan disusun selaras dengan strategi organisasi yang telah disebutkan pada bab sebelumnya. Dalam melakukan penyusunan peta strategi Direktorat Sistem Informasi akan kembali merujuk pada tahap kedua yaitu relevansi Direktorat Sistem Informasi berdasarkan peta strategi organisasi, sehingga akan menghasilkan strategi organisasi yang dapat didukung langsung oleh Direktorat Sistem Informasi. Berikut ini akan digambarkan penurunan sasaran strategi organisasi ke dalam empat perspektif balanced scorecard. 


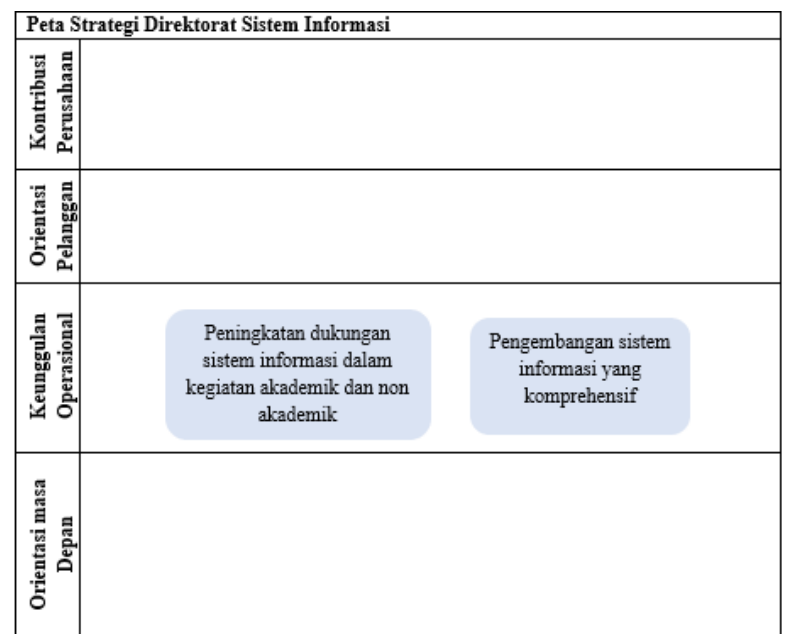

Gambar 3 Cascading Sasaran Strategi Perusahaan ke Strategi DIREKTORAT SISTEM INFORMASI (DSI)

Strategi "Peningkatan dukungan sistem informasi dalam kegiatan akademik dan non akademik" dan "Pengembangan sistem informasi yang komprehensif" termasuk dalam perspektif Keunggulan Operasional yang bertujuan untuk menjamin ketersediaan aplikasi dan infrastruktur TI dalam kondisi optimal sehingga dapat mendukung pelayanan akademik/non akademik universitas dan meningkatkan efisiensi kegiatan operasional dilingkungan universitas, bertujuan agar TI mampu mempermudah dan mempercepat waktu penyusunan perencanaan dan program kerja.

\subsection{Penyusunan Strategu berdasarkan Harapan Pelanggan DIREKTORAT SISTEM INFORMASI \\ (DSI)}

Penyusunan strategi ini didasarkan pada harapan pelanggan yang telah diidentifikasi pada tahap sebelumnya. Identifikasi harapan pelanggan didasarkan pada tujuan DIREKTORAT SISTEM INFORMASI (DSI), relevansi DIREKTORAT SISTEM INFORMASI (DSI) pada strategi organisasi, identifikasi pelanggan serta tugas pokok dan fungsi DIREKTORAT SISTEM INFORMASI (DSI). Oleh karena itu, penyusunan strategi didasarkan pada harapan pelanggan yang telah mewakili beberapa tahapan cascading strategi organisasi ke dalam fungsional bisnis DIREKTORAT SISTEM INFORMASI (DSI). Berdasarkan penyusunan strategi yang dilakukan, didapatkan 9 strategi DIREKTORAT SISTEM INFORMASI (DSI), yaitu: (1) Penguasaan teknologi informasi oleh sumber daya manusia universitas, (2) Peningkatan hubungan baik dengan vendor/supplier dan developer, (3) Peningkatan dukungan system informasi dalam kegiatan akademik dan non akademik, (4) Pengembangan system informasi yang komprehensif, (5) Optimalisasi pengelolaan asset teknologi informasi, (6) Peningkatan kepuasan pengguna teknologi informasi, (7) Peningkatan kompetensi dan profesionalitas sumber daya manusia DIREKTORAT SISTEM INFORMASI (DSI), (8) Optimalisasi pengawasan dan pemantauan infrastruktur dan layanan TI, (9) Peningkatan kinerja dalam penyelenggaraan kegiatan operasional akademik/non akademik.

\subsection{Pemetaan Strategi ke Perspektif BALANCE SCORECARD (BSC)}

Setelah dilakukan penyusunan strategi untuk melengkapi peta strategi Direktorat Sistem Informasi, strategi yang dirumuskan berdasarkan harapan pelanggan dan strategi yang diturunkan langsung dari strategi organisasi akan dipetakan ke dalam perspektif balanced scorecard, yaitu perspektif finansial, pelanggan, proses bisnis internal dan perspektif pertumbuhan dan pembelajaran. Pemetaan strategi tersebut akan dijabarkan pada gambar berikut. 


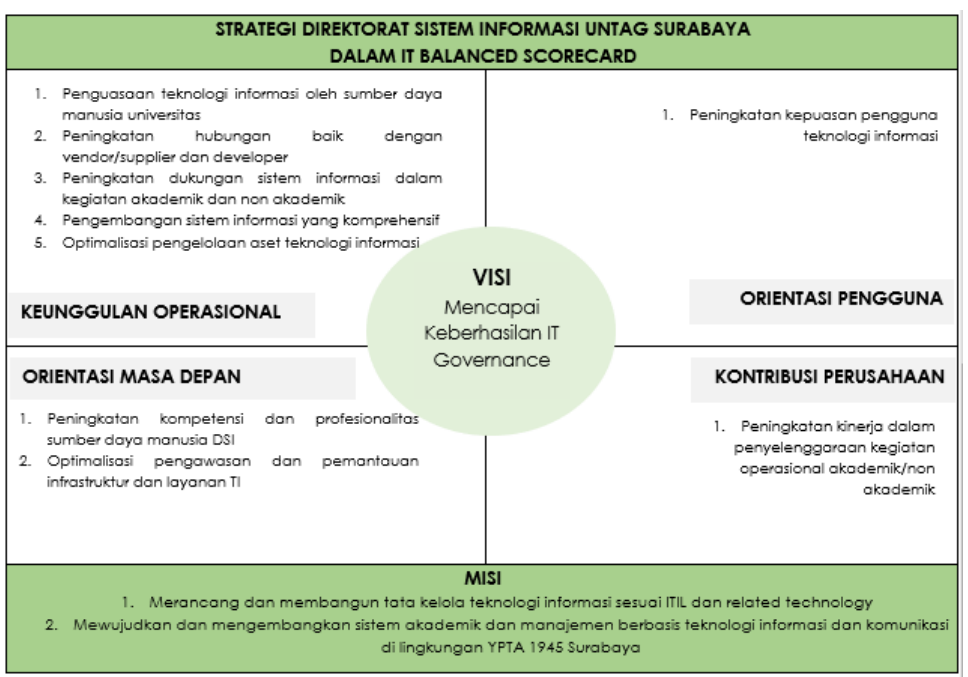

Gambar 4 Strategi DIREKTORAT SISTEM INFORMASI (DSI) dalam IT BALANCE SCORECARD

\subsection{Penyusunan Peta Strategi}

(BSC)

Pada tahap ini akan ditarik garis hubungan sebab-akibat dari strategi Bagian Program yang telah dipetakan kedalam empat perspektif IT Balanced Scorecard sehingga menjadi peta strategi Direktorat Sistem Informasi. Berikut ini akan digambarkan hubungan sebab-akibat pada peta strategi berikut.

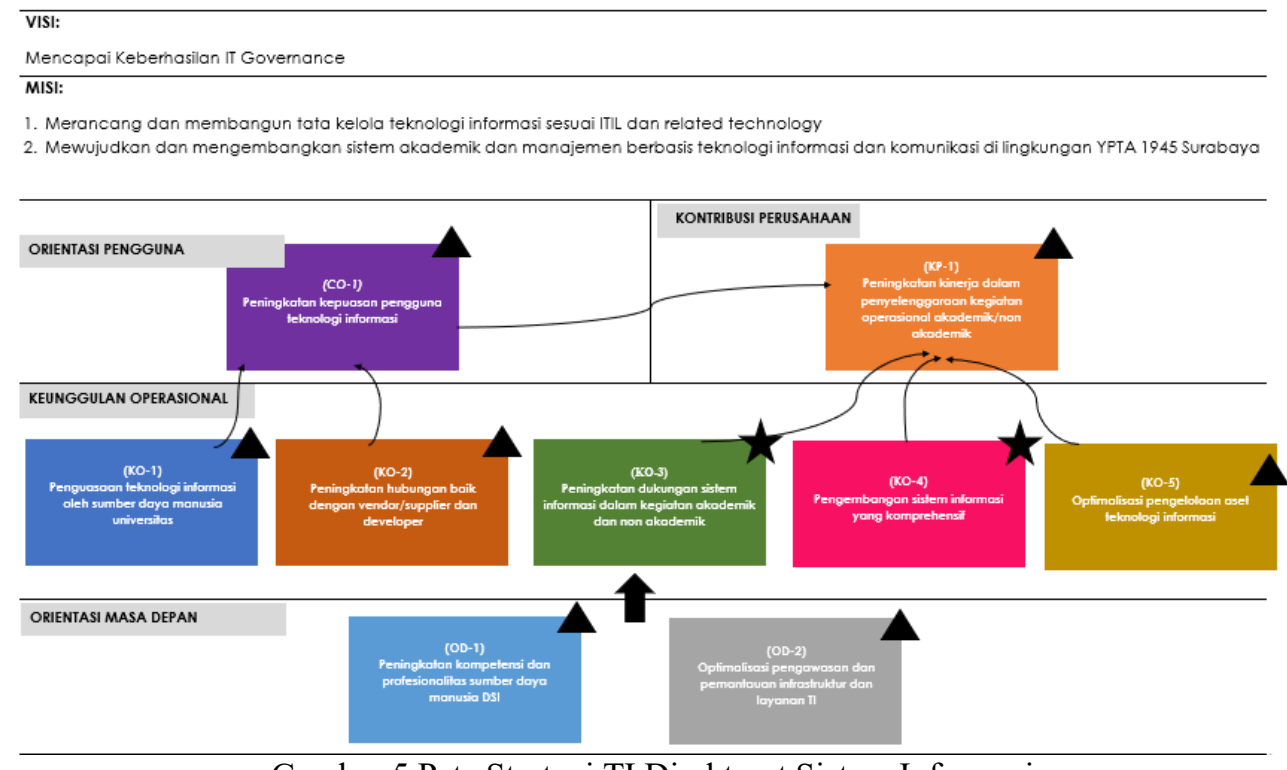

Gambar 5 Peta Strategi TI Direktorat Sistem Informasi

Strategi Direktorat Sistem Informasi dengan tanda segitiga merupakan sasaran strategi yang sudah dibuat mengacu pada tahapan cascading sebelumnya dan berhubungan dengan Direktorat Sistem Informasi, sedangkan strategi dengan tanda bintang merupakan sasaran strategi yang diperoleh dari peta strategi Balanced Scorecard Universitas 17 Agustus 1945 Surabaya.

Peta Strategi yang digambarkan pada Gambar 5 menunjukkan bahwa peningkatan kepuasan pengguna teknologi informasi yang akan berujung pada peningkatan kinerja dalam penyelenggaraan kegiatan operasional akademik/non akademik. Dalam mendukung peningkatan kepuasan pengguna TI, diperlukan strategi penguasaan TI oleh seluruh SDM universitas dan peningkatan hubungan dengan vendor TI. Sedangkan dalam mendukung peningkatan kinerja penyelenggaraan kegiatan operasional akademik/non akademik perlu didukung sistem informasi dan optimalisasi pengelolaan aset TI.

\subsection{Hasil Perumusan Key Performance Indicator dan Inisiatif Strategi}

Setelah menyusun strategi dan peta strategi Direktorat Sistem Informasi, maka langkah selanjutnya adalah merumuskan key performance indicator (KPI) dan inisitaif strategi. KPI adalah indikator-indikator yang digunakan untuk mengukur kinerja. KPI mempunyai peranan yang sangat penting karena setiap strategi dan 
peta strategi yang telah disusun perlu untuk dipantau dan diukur tingkat pencapaiannya. Setelah menentukan KPI selanjutnya menentukan inisiatif strategi pada setiap sasaran strategi yang digunakan untuk dapat mencapai KPI nantinya semua indikator-indikator dapat terpenuhi dengan baik sesuai dengan target yang ditentukan oleh organisasi. Dalam merumuskan KPI dan inisiatif strategi, diperlukan metode analisis CSF untuk mengidentifikasi inisiatif strategi atau aksi dan KPI yang tepat dalam mencapai strategi DSI. Berikut ini akan dijabarkan analisis Critical Success Factor (CSF) untuk setiap strategi yang telah dirumuskan sebelumnya untuk mendapatkan Key Performance Indicator (KPI) dan aksi (inisiatif strategi/program kerja) yang dijabarkan pada tabel berikut.

Tabel 1 KPI dan Inisiatif Strategi

\begin{tabular}{|c|c|c|c|c|}
\hline Perspektif & $\begin{array}{l}\text { Strategi Direktorat } \\
\text { Sistem Informasi }\end{array}$ & Poin Strategi & Key Performance Indicator & $\begin{array}{c}\text { Inisiatif Strategi/Program } \\
\text { Kerja }\end{array}$ \\
\hline $\begin{array}{l}\text { Kontribusi } \\
\text { Perusahaan }\end{array}$ & $\begin{array}{l}\text { Peningkatan kinerja } \\
\text { dalam penyelenggaraan } \\
\text { kegiatan operasional } \\
\text { akademik/non akademik }\end{array}$ & $\begin{array}{l}\text { Memudahkan dan } \\
\text { memperpendek } \\
\text { waktu } \\
\text { penyelenggaraan } \\
\text { kegiatan } \\
\text { operasional } \\
\text { akademik/non } \\
\text { akademik }\end{array}$ & $\begin{array}{l}\text { Waktu penyelesaian setiap } \\
\text { kegiatan operasional } \\
\text { akademik/non akademik }\end{array}$ & $\begin{array}{l}\text { Pengembangan teknologi } \\
\text { informasi dalam mendukung } \\
\text { aktivitas non } \\
\text { akademik/akademik }\end{array}$ \\
\hline $\begin{array}{l}\text { Orientasi } \\
\text { Pengguna }\end{array}$ & $\begin{array}{l}\text { Peningkatan kepuasan } \\
\text { pengguna teknologi } \\
\text { informasi }\end{array}$ & $\begin{array}{l}\text { Mengetahui tingkat } \\
\text { kepuasan pengguna } \\
\text { teknologi informasi }\end{array}$ & $\begin{array}{l}\text { Indeks kepuasam pengguna } \\
\text { teknologi informasi }\end{array}$ & $\begin{array}{l}\text { Evaluasi dan monitoring } \\
\text { pelayanan terkait teknologi } \\
\text { informasi dalam organisasi }\end{array}$ \\
\hline \multirow{5}{*}{$\begin{array}{l}\text { Keunggulan } \\
\text { Operasional }\end{array}$} & $\begin{array}{l}\text { Penguasaan teknologi } \\
\text { informasi oleh SDM } \\
\text { universitas }\end{array}$ & $\begin{array}{l}\text { Meningkatkan } \\
\text { kemampuan TI } \\
\text { seluruh SDM } \\
\text { dalam universitas }\end{array}$ & $\begin{array}{ll}\text { - } & \text { Jumlah pelatihan yang } \\
\text { diadakan } \\
\text { - } & \text { Jumlah pegawai yang } \\
\text { lulus dalam pelatihan TI } \\
\text { - } \quad \text { Rata-rata nilai post-test } \\
\text { pelatihan TI }\end{array}$ & $\begin{array}{ll}- & \text { Pengembangan metode } \\
\text { pelatihan TI yang efektif } \\
\text { - } \\
\text { Peningkatan kapasitas } \\
\text { sumber daya }\end{array}$ \\
\hline & $\begin{array}{l}\text { Peningkatan hubungan } \\
\text { baik dengan } \\
\text { vendor/supplier dan } \\
\text { developer }\end{array}$ & $\begin{array}{l}\text { Meningkatkan } \\
\text { kerja sama dengan } \\
\text { suatu vendor, } \\
\text { supplier atau } \\
\text { developer TI dalam } \\
\text { kaitannya dengan } \\
\text { pengembangan } \\
\text { aplikasi, } \\
\text { pengadaan dan } \\
\text { pemeliharaan } \\
\text { infrastruktur TI }\end{array}$ & $\begin{array}{llr}\text { - } & \text { Jumlah kontrak yang } \\
\text { diperpanjang } & \\
\text { - } & \text { Jumlah keluhan yang } \\
\text { dilayani } & \text { pihak } \\
\text { vendor/supplier } & \text { dan } \\
\text { developer } & \end{array}$ &  \\
\hline & $\begin{array}{l}\text { Peningkatan dukungan } \\
\text { sistem informasi dalam } \\
\text { kegiatan akademik dan } \\
\text { non akademik }\end{array}$ & $\begin{array}{l}\text { Mengembangan } \\
\text { sistem informasi } \\
\text { yang sesuai dengan } \\
\text { kebutuhan dalam } \\
\text { kegiatan akademik } \\
\text { dan non akademik }\end{array}$ & $\begin{array}{l}\text { - } \begin{array}{l}\text { Jumlah aplikasi baru } \\
\text { yang } \\
\text { diimplementasika n tiap }\end{array} \\
\text { tahun } \\
\text { Jumlah aplikasi yang } \\
\text { telah diimplementasika } \\
\text { n } \\
\text { Jumlah aplikasi yang } \\
\text { dibangun berdasarkan } \\
\text { permintaan }\end{array}$ & 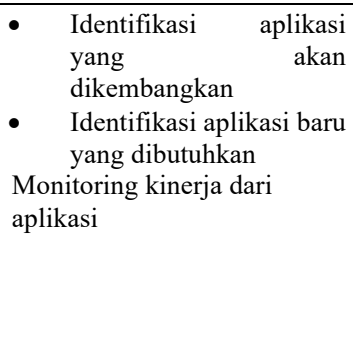 \\
\hline & $\begin{array}{l}\text { Pengembangan sistem } \\
\text { informasi yang } \\
\text { komprehensif }\end{array}$ & $\begin{array}{l}\text { Mengembangkan } \\
\text { aplkasi yangs esuai } \\
\text { dengan kebutuhan } \\
\text { universitas dan } \\
\text { berkualitas }\end{array}$ & $\begin{array}{l}\text { - Jumlah aplikasi baru } \\
\text { yang akan } \\
\text { diimplementasika n tiap } \\
\text { tahun } \\
\text { Jumlah aplikasi yang } \\
\text { telah diimplementasika } \\
\mathrm{n} \\
\text { Rata-rata waktu yang } \\
\text { dibutuhkan untuk } \\
\text { memenuhi permintaan } \\
\text { pengguna } \\
\text { Persentase tingkat } \\
\text { kehandalan aplikasi }\end{array}$ & 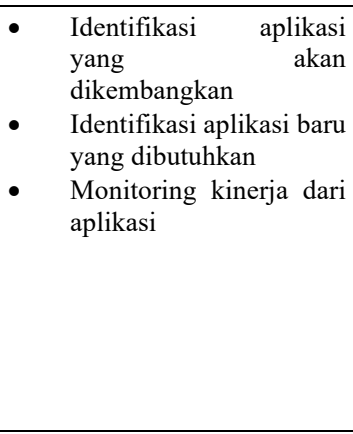 \\
\hline & $\begin{array}{l}\text { Optimalisasi } \\
\text { pengelolaan aset } \\
\text { teknologi informasi }\end{array}$ & $\begin{array}{l}\text { Mengetahui selisih } \\
\text { rencana anggaran } \\
\text { dengan realisasi } \\
\text { anggaran untuk } \\
\text { pengelolaan aset TI }\end{array}$ & $\begin{array}{l}\text { Persentase tingkat } \\
\text { ketercapaian anggaran }\end{array}$ & $\begin{array}{l}\text { Penyusunan laporan hasil } \\
\text { pelaksanaan rencanan } \\
\text { program dan anggaran }\end{array}$ \\
\hline
\end{tabular}




\begin{tabular}{|c|c|c|c|c|}
\hline Perspektif & $\begin{array}{l}\text { Strategi Direktorat } \\
\text { Sistem Informasi }\end{array}$ & Poin Strategi & Key Performance Indicator & $\begin{array}{c}\text { Inisiatif Strategi/Program } \\
\text { Kerja }\end{array}$ \\
\hline & & $\begin{array}{l}\text { (surplus atau } \\
\text { defisit anggaran) }\end{array}$ & & \\
\hline \multirow[t]{2}{*}{$\begin{array}{l}\text { Orientasi Masa } \\
\text { Depan }\end{array}$} & $\begin{array}{l}\text { Peningkatan kompetensi } \\
\text { dan profesionalitas SDM } \\
\text { DIREKTORAT } \\
\text { SISTEM INFORMASI } \\
\text { (DSI) }\end{array}$ & $\begin{array}{l}\text { Meningkatkan } \\
\text { kemampuan dan } \\
\text { pengetahuan dalam } \\
\text { mendukung } \\
\text { operasional } \\
\text { DIREKTORAT } \\
\text { SISTEM } \\
\text { INFORMASI } \\
\text { (DSI) }\end{array}$ & $\begin{array}{l}\text { - Jumlah karyawan yang } \\
\text { lulus pelatihan } \\
\text { - Jumlah karyawan yang } \\
\text { lulus sertifikasi } \\
\text { - Skor penilaian kinerja } \\
\text { pegawai }\end{array}$ & $\begin{array}{l}\text { Peningkatan kapasitas } \\
\text { sumber daya }\end{array}$ \\
\hline & $\begin{array}{l}\text { Optimalisasi } \\
\text { pengawasan dan } \\
\text { pemantauan infrastruktur } \\
\text { dan layanan TI }\end{array}$ & $\begin{array}{l}\text { Mengoptimalkan } \\
\text { maintenance } \\
\text { infrastruktur dan } \\
\text { layanan TI }\end{array}$ & $\begin{array}{l}\text { Rata-rata kegiatan } \\
\text { monitoring per tahun/per } \\
\text { bulan }\end{array}$ & $\begin{array}{l}\text { Monitoring dan maintenance } \\
\text { aplikasi }\end{array}$ \\
\hline
\end{tabular}

\section{Kesimpulan}

Berdasarkan penelitian yang telah dilakukan mengenai pembuatan peta strategi TI dengan menerapkan tahapan cascading balance scorecard, dapat ditarik kesimpulan yaitu:

1. Peta strategi DIREKTORAT SISTEM INFORMASI (DSI) terdiri dari 9 (sembilan) strategi yang dihasilkan dari proses cascading hasil Balanced Scorecard. Terdapat 2 (dua) strategi bisnis Universitas 17 Agustus 1945 Surabaya yang langsung diturunkan pada strategi Direktorat Sistem Informasi. Sedangkan 6 (enam) strategi diantaranya didapatkan dari tugas pokok dan fungsi serta harapan pelanggan Direktorat Sistem Informasi yang terdiri dari 1 (satu) strategi pada perspektif kotribusi perusahaan, 1 (satu) strategi pada perspektif orientasi pengguna, 3 (tiga) strategi pada perspektif keunggulan operasional dan 2 (dua) strategi pada orientasi masa depan.

2. Peta strategi TI yang dihasilkan mengarah pada peningkatan kepuasan pengguna teknologi informasi yang akan berujung pada peningkatan kinerja dalam penyelenggaraan kegiatan operasional akademik/non akademik. Dalam mendukung peningkatan kepuasan pengguna TI, diperlukan strategi penguasaan TI oleh seluruh SDM universitas dan peningkatan hubungan dengan vendor TI. Sedangkan dalam mendukung peningkatan kinerja penyelenggaraan kegiatan operasional akademik/non akademik perlu didukung sistem informasi dan optimalisasi pengelolaan aset TI.

\section{Acknowledgements}

Ucapan terima kasih, disampaikan kepada pihak-pihak yang telah membantu terlaksananya penelitian ini dengan kesediaannya menjadi studi kasus sekaligus lokasi penggalian data yaitu Direktorat Sistem Informasi Universitas 17 Agustus 1945 Surabaya.

\section{Referensi}

[1] KPMG, "KPMG," 1 Oktober 2018. [Online]. Available: http://www.kpmg.com/US/en/IssuesAndInsights/ArticlesP ublications/Documents/technology-outlooksurvey2013.pdf.

[2] "IDC," 2014. [Online]. Available: http://www.idc.co.id.

[3] P. B. S. Luis, Step by Step in Cascading Balanced Scorecard to Functional Scorecards, Jakarta: Gramedia Pustaka Utama, 2007.

[4] D. P. N. R. S. Kaplan, "The Balanced Scorecard: Translating Strategy into Action," Harvard Business School Press, 1996.

[5] W. V. Grembergen, "IT Balanced Scorecard and IT Governance," Information System Journal, 2000.

[6] P. Niven, Balanced Scorecard step-by-step: Maximizing performance and maintaining results, West Susses: Wiley Publishing, 2002. 